\title{
INITIAL EVALUATION OF IMPACT OF EVENNESS OF SPREADING WOOD ASH IN FOREST ON ADDITIONAL RADIAL INCREMENT
}

\author{
Modris Okmanis ${ }^{1}$, Toms Kalvis ${ }^{2}$, Dagnija Lazdina ${ }^{1}$ \\ ${ }^{1}$ Latvian State Forest Research Institute "Silava", Latvia; \\ ${ }^{2}$ Latvia University of Life Sciences and Technologies, Latvia \\ modris.okmanis@silava.lv, kalvistoms@gmail.com,dagnija.lazdina@silava.lv
}

\begin{abstract}
One of the most feasible options for utilization of wood ash obviously is to improve the forest growth conditions, particularly in fertilization of drained forests and peatlands, where the positive impact on tree growth response is observed by many studies in boreal and temperate moist climate zone. Forest fertilization as forestry measure meets several obstacles. One of the main is evenness of mechanized spreading, which is affected by the strip road configuration and stand density. It is also difficult to provide even spread of ash because of variable texture if untreated ash is used. The aim of this study is to determine how far from the fertilized area tree growth is affected. Experiment was established in 3 Norway spruce stands on drained forest soils. In each stand 9 systematically located $20 \times 20 \mathrm{~m}$ sample plots were set. Tree measurements were made before fertilization and increment cores were collected 5 growing seasons after fertilization from trees in the sample plots and trees in different distances from the sample plots to determine annual radial increments. Cumulative additional radial increment varied from 0.95 to $3.58 \mathrm{~mm}$ in the ash fertilized plots. Significant and positive $\left(t=4.68>t_{0.05 ; 37}=1.69\right)$ effect of wood ash in outer $10 \mathrm{~m}$ zone of the fertilized plots was observed only in 1 spruce stand, which could be partly explained by leaching of biogenic elements and distribution of roots.
\end{abstract}

Keywords: wood ash, fertilization, additional increment.

\section{Introduction}

Wood is number one renewable energy resource in Latvia and consumption of woody biomass is increasing every year. Increasing demand and removals of biomass require to improve the tree growth conditions, for example, by proper thinning, amelioration and other forestry operations, however productivity of forest stands can be significantly increased by fertilization [1-3]. Another issue related to biomass consumption is utilization of wood ash, which so far is mostly considered as waste. However, it consists from considerable amount of micro and macro elements, like calcium, magnesium, potassium, phosphorus, manganese, zinc etc. [4-6], which induce positive impact on tree growth in certain site conditions [7-9]. By now fertilization with wood ash has been conducted in many different forest sites worldwide, however, the best results are obtained on drained organic soils, where deficiency of certain chemical elements like phosphorus and potassium has been found.

Scientific fertilization experiments mostly are conducted manually, but, when it comes to profitability, mechanized options shall be considered. There are many different options for mechanized fertilization, which could be divided in 2 larger groups by the type of vehicles - ground and aircraft based. As an aircraft helicopters and planes can be used. Drone technologies are on their way. Ground based fertilizer spreading can be done by more vehicles - forest forwarders, agricultural tractors, small size forestry, agriculture machines etc. The spreading quality is influenced by various factors like uneven relief, wet local areas, number and location of growing trees, larger stumps, wind etc. [10-13]. For example, wood ash particles hit stems of growing trees and do not reach more distant locations.

In context of this problem, it is essential to clarify, if it is necessary to improve ground based technologies, which could provide better spreading quality, or it is sufficient to scatter wood ash in regular, but rather narrow zones to provide positive fertilization effect. The aim of this study is to determine how far from the fertilization zone positive effect on tree growth can be observed.

\section{Materials and methods}

Experiment was established in three middle aged Norway spruce (Picea abies) stands on drained mineral (Myrtillosa mel.) and peat (Myrtillosa turf. mel.) soils. Summary of stand variables is shown in Table 1. In summer 2011 nine $20 \times 20 \mathrm{~m}$ sample plots with $11 \mathrm{~m}$ buffer zone between them were set in each stand. In all plots the diameter at the breast height of each tree and the height of 10 trees per plot were measured to build up the height curve. 
Description of experimental sites

Table 1

\begin{tabular}{|c|c|c|c|c|c|c|c|c|}
\hline Exp. & $\begin{array}{c}\text { Forest } \\
\text { type }\end{array}$ & Age & $X^{* *}$ & $Y^{* * * *}$ & $D^{* * * *}, \mathrm{~cm}$ & $\boldsymbol{H}^{* * * * *}, \mathbf{m}$ & $\begin{array}{c}\text { Basal area, } \\
\mathbf{m}^{2} \cdot \mathbf{h a}^{-1}\end{array}$ & $\begin{array}{c}\text { Growing stock, } \\
\mathbf{m}^{3} \cdot \mathbf{h a}^{-1} \\
\end{array}$ \\
\hline $16-10$ & $K s^{*}$ & 47 & $56^{\circ} 51^{\prime} 25^{\prime \prime}$ & $23^{\circ} 40^{\prime} 45^{\prime \prime}$ & $23.28 \pm 0.50$ & $18.60 \pm 0.19$ & $16.05 \pm 0.11$ & $144.26 \pm 0.95$ \\
\hline $17-7$ & $K s^{*}$ & 43 & $56^{\circ} 51^{\prime} 32^{\prime \prime}$ & $23^{\circ} 41^{\prime} 23^{\prime \prime}$ & $26.03 \pm 0.53$ & $19.33 \pm 0.15$ & $23.31 \pm 0.07$ & $209.50 \pm 0.62$ \\
\hline $41-14$ & $A s^{*}$ & 36 & $23^{\circ} 27^{\prime} 35^{\prime \prime}$ & $23^{\circ} 27^{\prime} 35^{\prime \prime}$ & $22.03 \pm 0.60$ & $18.34 \pm 0.19$ & $18.15 \pm 0.07$ & $164.44 \pm 0.61$ \\
\hline
\end{tabular}

*Ks - Myrtillosa turf. mel.; As - Myrtillosa mel.; **X-latitude; ***Y-longitude; ****D-diameter at breast height; $* * * * * H-$ height.

In June, 2011 in 3 plots of each stand 2.5 tonnes $^{-1} a^{-1}$ of wood ash (WA) were spread, in other 3 plots potassium sulphate $(\mathrm{M})$ was spread and the rest 3 plots remained as control without any fertilizer (C). By spreading 2.5 tonnes ha ${ }^{-1}$ of wood ash about $65 \mathrm{~kg} \mathrm{ha}^{-1}$ of potassium were brought into soil, although wood ash contains other micro and macro elements, which are shown in Table 2.

Table 2

\section{Element content in wood ash and dose [9]}

\begin{tabular}{|c|c|c|}
\hline Element & Content, $\mathbf{g} \cdot \mathbf{k g}^{-\mathbf{1}}$ & Dose, $\mathbf{~ k g} \cdot \mathbf{h a}^{\mathbf{- 1}}$ \\
\hline $\mathrm{P}$ & 10.9 & 27.3 \\
\hline $\mathrm{K}$ & 26.0 & 65.0 \\
\hline $\mathrm{Ca}$ & 224.8 & 562.0 \\
\hline $\mathrm{Mg}$ & 30.9 & 77.3 \\
\hline $\mathrm{Mn}$ & 3.1 & 7.8 \\
\hline
\end{tabular}

During August, 2017 increment core samples at the breast height of 10 trees per each WA and C plot were collected. Increment core samples were also collected from trees in up to $10 \mathrm{~m}$ radius around borders of WA sample plots following the scheme in Fig. 1. Distance to the border of WA plots for each sample tree was measured. In total 364 increment core samples were collected. The samples were glued to a pad and the surface was grinded so that each radial increment could be easily identified. The prepared samples were scanned with high resolution hardware Epson Expression 10000 XL scanner. Measurement of radial increments was done using WinDENDRO software with $0.001 \mathrm{~mm}$ precision.

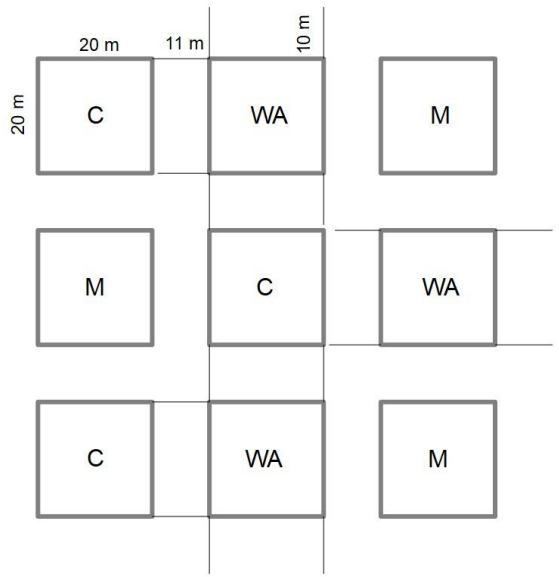

Fig. 1. Scheme of plot location

Mean values of all stand variables were calculated - diameter, height, basal area and stock volume. Average radial increments were calculated for the last 17 years (12 years of retrospection period and 5 years of fertilization effect) of each trial, except the increment in 2017, which was not fully formed. Regression analysis between $\mathrm{C}$ and WA tree radial increments in retrospection period was done at the first step to determine additional increment, which was induced by wood ash. As a result regression equation was elaborated to transform the actual $\mathrm{C}$ radial increments into prognostic increments. Additional radial increment is the difference between actual WA and prognostic increment [14]. 
Additional radial increment of each sample tree around WA plot was calculated following to similar calculations as for trees in the fertilized plots. At first trees with significant correlation $\left(r_{12 ; 0.05}>0.576\right)$ of radial increments in the retrospection period were selected. Then additional radial increment of each sample tree was calculated. Correlation analysis between the distance of the sample tree to WA plot and cumulative additional radial increment (5 year period) was conducted to determine, how far from the border of the ash spreading the effect of wood ash from the treated area could be found. Significance of the difference between the cumulative radial increment of average sample tree and prognostic values in the impact period was evaluated with the t-test [15].

To find out, if there was any possible unequal leaching of nutrients from a plot, which could affect the radial increment outside the plot, the terrain model was elaborated using LiDAR data (4 points per $\mathrm{m}^{2}$ ). At first, a digital elevation model (DEM) using the triangulated irregular network (TIN) method with Global Mapper v16 software was made. Further web of streams was modelled using QGIS //2.18.12/ software. To model water runoff, DEM was processed with /Fill Sinks/ algorithm. Then catchment area was modelled with SAGA GIS tool /Catchment area/. At the end SAGA GIS tool /Channel Network/ was used to model the potential stream locations pointing to potential unequalities of nutrients leaching from thee fertlized plots.

\section{Results and discussion}

Observations of radial increment allow to study the effect of environmental conditions on tree growth. Norway spruce is a sensitive tree species, which reflects different environmental changes. In the study area reduction of radial increment could be seen already starting from the year 2004 by unknown factors, however, the peak of radial increment reduction was in 2010, when invasion of spruce bud scale was observed $[7 ; 20]$. By analysing tree growth in the retrospective period (from 2000 to 2011), it was concluded that there is a significant and positive correlation $(r>0.93, \alpha=0.05)$ between the control and wood ash plots. Using the acquired regression equation the prognostic (Prog) increment values were calculated. Annual additional radial increment, which was induced by wood ash, was calculated as the difference between radial increment in WA plots and prognostic values. Cumulative additional radial increment values were $3.58,0.95$ and $1.88 \mathrm{~mm}$, respectively. $\mathrm{M}$. Okmanis et. al. concludes that wood ash improves the tree growth already after the first year and the positive effect continues for all 4 observation years [9].

This study approves that immediate effect can be seen during the $1^{\text {st }}$ year after fertilization, however, in the $5^{\text {th }}$ year reduction of increment can be observed, Fig. 2. Lỉbiete et. al. Find a similar tendency of additional increment reduction after 10 years from fertilization [16]. Saarsalmi et. al. observed positive effect of wood ash fertilization only after the $6^{\text {th }}$ year from fertilization, which could be explained by use of stabilized ash, however, additional stock increment was by $25 \%$ higher than in the control plots during the following 10 years [17]. However, changes in the element content of tree canopy could be found even 30 years after fertilization with wood ash $[18 ; 19]$. In this case the fact that during 2010 and 2011 these stands were under impact of stress factors [7;20] and addition of biogenic elements induced faster stand recovery should be taken into account. It is considered that in normal situation the result would not be so remarkable. The effect of fertilization is similar in all 3 stands, however, the highest increments can be observed in 16-10 experiments, where the basal area and therefore competition between individual trees is the smallest. This finding approves the demand for optimisation of the stand density, if maximum effect of fertilization is expected.

It is well known that spruce roots are spread in a distance of several meters around the tree and fine roots are mostly distributed in the upper layer of the soil [21], therefore, there is a high possibility that trees outside the sample plots can use nutrients applied with wood ash. Cumulative additional radial increment of each tree outside the fertilized plot was calculated as a sum of radial additional increments of the last 5 years. Theoretically, if a tree is located closer to the fertilized area of the plot, larger amounts of the roots reach into the fertilized area. Using the correlation analyses it was found that additional radial increment does not depend on the distance from the fertilized sample plots, Fig. 3 , therefore, all trees in $10 \mathrm{~m}$ distance from the border of the fertilized area were combined into one group to determine the fertilization effect outside the area treated with wood ash. 

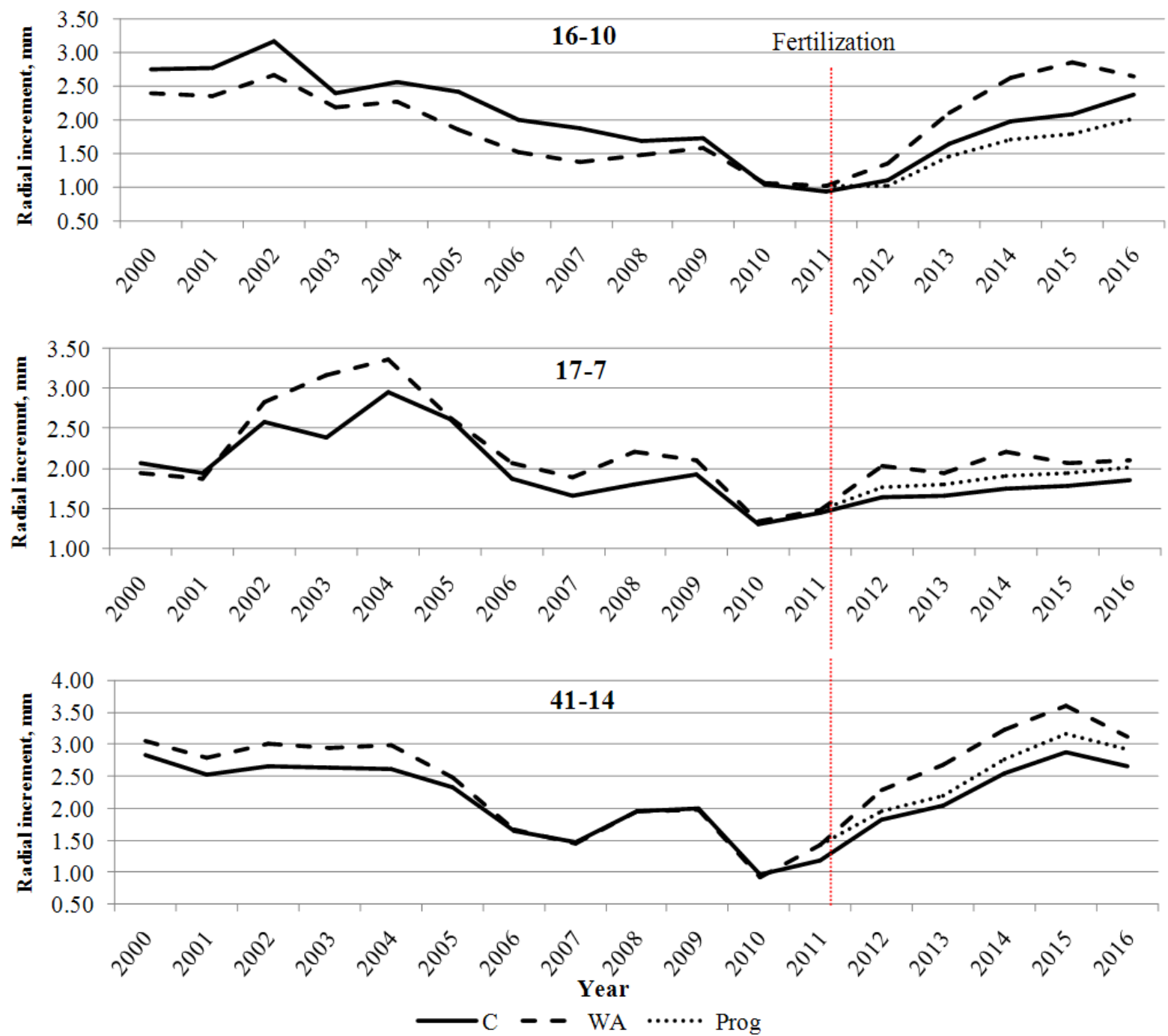

Fig. 2. Average radial increment values and prognostic increment in fertilized and control plots

Actual cumulative radial increment values were compared with the theoretical using the t-test. It was found that only in one stand (16-10) the actual radial increment significantly differed from the prognostic values $\left(t=4.68>t_{0.05 ; 37}=1.69\right)$ and average cumulative radial increment was positive $(4.2 \pm 0.9 \mathrm{~mm})$. The same stand shows the best increment results in the fertilized plots. It is also the oldest stand and the reason of higher increment values can be wider distribution of roots around the trees. Cumulative radial increments of the stand 41-14 do not differ significantly $\left(t=0.93<t_{0.05 ; 39}=1.68\right)$ from the prognostic values, so the hypothesis that additional increment of trees outside the fertilized area is 0 can be accepted. Statistically significant $\left(t=2.05>t_{0.05 ; 33}=1.69\right)$, but negative $(-0.7 \pm 0.5)$ cumulative additional radial increment was observed in the stand 17-7, however, the value is close to 0 . Tendencies of formation of the additional radial increment of trees outside the fertilized area are similar to those inside the fertilized sample plots, which can be explained by the influence of the stand density.

Already during the $1^{\text {st }}$ year after fertilization leaching of bigenic elements in deeper soil layers was observed [8] and other authors also observed leaching of potassium ions from fertilized area to catchment [22-24], so there is a possibility that elements, forced by terrain, could leach out from the sample plots. To find the possible direction of element leaching, stream web was modelled.

As displayed in Fig. 4, none of the experimental areas has steep terrain, however, the obtained model enables to analyse the possible water flow directions influenced by microrelief. Possible water flow from the WA plot to the outer plot zone was observed in the stand 16-10 - the same stand, where 
positive additional radial increment was observed. However, to confirm the hypothesis of element leaching out of the fertilized zone lysimeters in different soil layers and stand zones should be set and seasonal dynamics of element concentration in soil solution should be analysed, while tree increment is influenced by multiple factors.

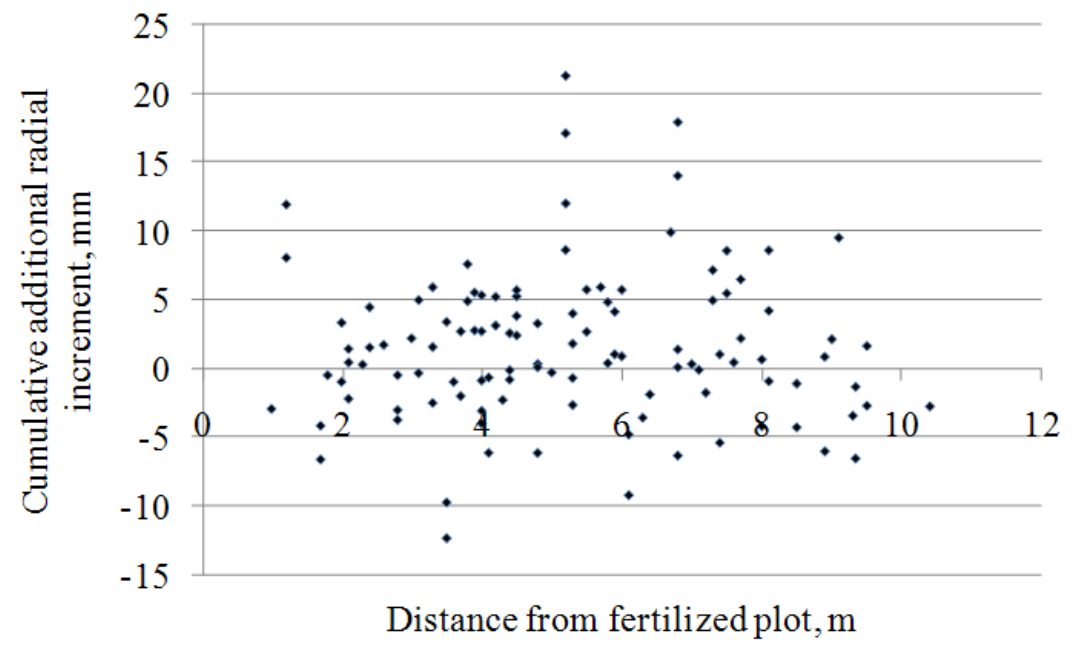

Fig. 3. Cumulative additional radial increment depending on distance betwween tree and border of fertilized plot
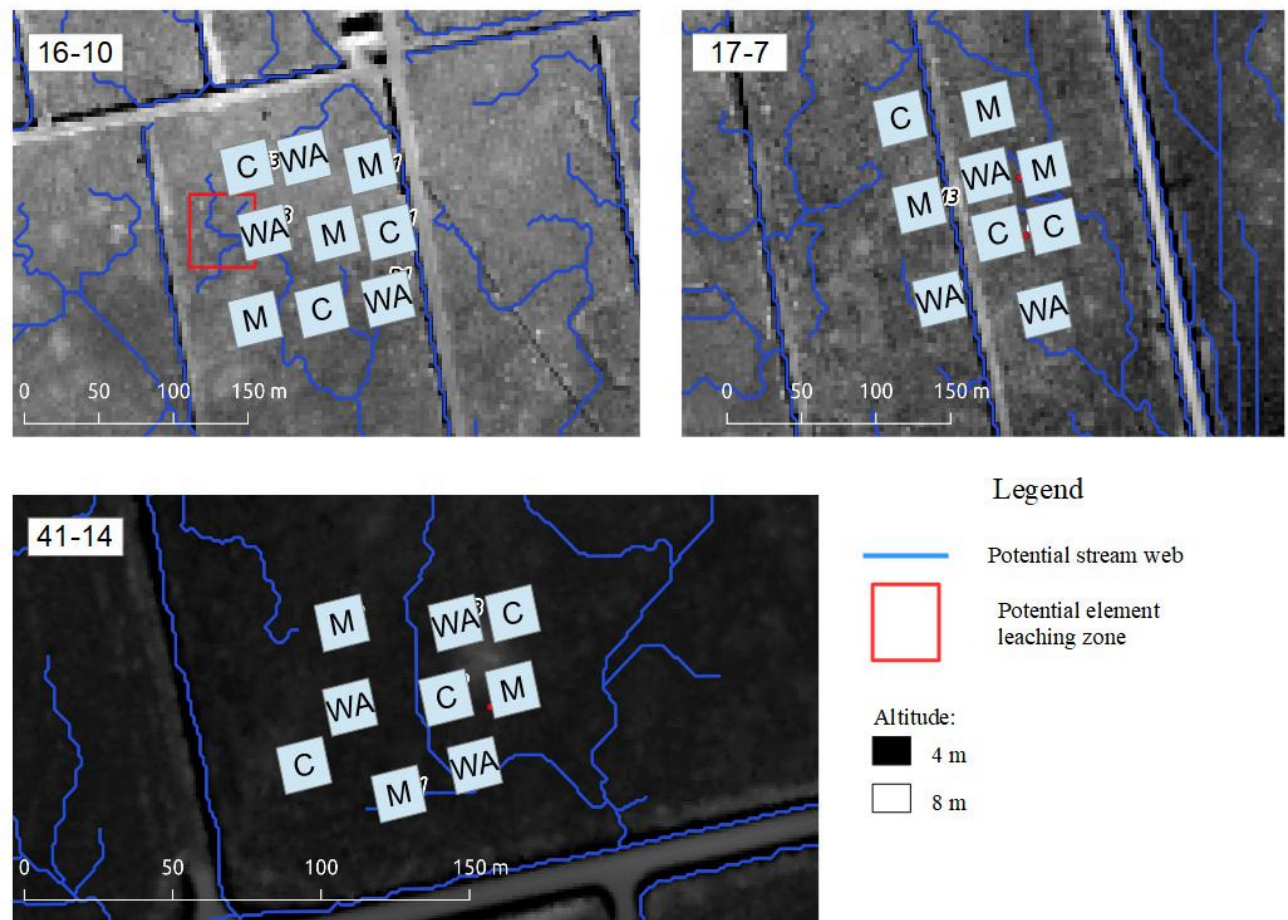

Legend

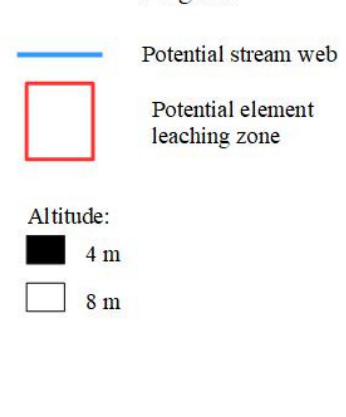

Fig. 4. Model of potentional runoff water stream web

Although positive additional increment was observed only in one of the three stands in $10 \mathrm{~m}$ zone outside the fertilized area, when the manual ash spreading method is applied, studies in areas, where mechanized ash spreading is applied, should be done. While larger areas are treated in the second case and uneven ash distribution is conducted.

\section{Conclusions}

Wood ash fertilization induced positive tree growth response, cumulative additional radial increment in the five year period varied from 0.95 to $3.58 \mathrm{~mm}$, but the effect was reduced in the $5^{\text {th }}$ year after fertilization. 
No correlation between the distance to the border of the fertilized area and additional radial increment was found and only in one experiment (16-10) cumulative additional radial increment of trees in $10 \mathrm{~m}$ zone around the fertilized plots was positive $(4.2 \pm 0.9 \mathrm{~mm})$ and significant $\left(t=4.68>t_{0.05 ; 37}=1.69\right)$, which can be partly explained by possible element leaching and the stand characteristics.

Further studies are necessary to evaluate the effect of large scale applications, where wood ash is spread near strip-roads mechanically.

\section{Acknowledgment}

The study is implemented within the scope of the Forest Sector Competence Center project No. 1.2.1.1/16/A/009.

\section{References}

[1] Bergh J., Linder S., Lundmark T., Elfving B. The effect of water and nutrient availability on the productivity of Norway spruce in northern and southern Sweden. Forest Ecology and Management, vol. 119(1-3), 1999, pp. 51-62.

[2] Hedwall P.-O., Gong P., Ingerslev M., Bergh J. Fertilization in northern forests - biological, economic and environmental constraints and possibilities. Scandinavian Journal of Forest Research, vol. 29(4), 2014, pp. 301-311.

[3] Moilanen M., Hytönen J., Hökkä H., Ahtikoski A. Fertilization increased growth of Scots pine and financial performance of forest management in a drained peatland in Finland. Silva Fennica, vol. 49(3), 2015, pp. 1-18.

[4] Werkelin J., Skrifvars B.-J., Hupa M. Ash-forming elements in four Scandinavian wood species. Part 1: Summer harvest. Biomass and Bioenergy, vol. 29(6), 2005, pp. 451-466.

[5] Werkelin J., Skrifvars B.-J., Zevenhoven M., Holmbom B., Hupa M. Chemical forms of ashforming elements in woody biomass fuels. Fuel, vol. 89(2), 2010, pp. 481-493.

[6] Okmanis M., Lazdiņa D., Lazdiņš A. The Composition and Use Value of Tree Biomass Ash. Rural Sustainability Research, vol. 34(329). 2015, pp. 32-37.

[7] Lazdinš̌ A., Miezīte O., Bārdule A. Characterization of severe damages of spruce (Picea abies (L.) H.Karst.) stands in relation to soil properties. Proceedings of international scientific conference „Research for rural development”, Jelgava, Latvia, 2011, pp. 22-29.

[8] Ermane E., Bardule A., Balcerbule Z., Gigele R. Macro Element Content in Fertilized Forest Soils in Spruce (Picea Abies (L.) H. Karst.) Stands in Latvia. Latvian Journal of Chemistry, vol. 51(4), 2012, pp. 291-295.

[9] Okmanis M., Skranda I., Lazdiņš A., Lazdiņa D. Impact of wood ash and potassium sulphate fertilization on growth of Norway spruce stand on organic soil. Proceedings of international scientific conference „Research for rural development”, 2016, Jelgava, Latvia, pp. 62-68.

[10] Barker P. R. Factors affecting aerial distribution of fertilizers to forests. Proceedings of international scientific conference „Regional Forest Nutrition Research Project”, 1979, Washington, USA, pp. 196-204.

[11] Kvamme R. Equipment for aerial fertilizatin. Proceedings of international scientific conference „Regional Forest Nutrition Research Project”, 1979, Washington, USA, pp. 194-195.

[12] Vesterinen P. Wood ash recycling - state of the art in Finland and Sweden. Research report No. PRO2/6107/03. Jyväskylä: Technical research centre of Finland, 2003. 52 p.

[13]Emilsson S. From extraction of forest fuels to ash recycling. Jönköping: Swedish forest agency, 2006. $41 \mathrm{p}$.

[14] Šmits A., Striķe Z., Liepa I. Priežu rūsganās zāğlapsenes (Neodiprion sertifer Geoffr.) izraisītās defoliācijas ietekme uz priežu (Pinus sylvestris L.) pieaugumu (Effect of defoliation caused by European pine sawfly Neodiprion sertifer Geoffr. on Scots pine Pinus sylvestris L.). Mežzinātne, 18(51), 2008, pp. 53-73.

[15] Liepa I. Biometrija (Biometry). Rīga: Zvaigzne. 1974. 336 p.

[16]Libiete Z., Bardule A., Lupikis A. Long-term effect of spruce bark ash fertilization on soil properties and tree biomass increment in a mixed scots pine-Norway spruce stand on drained organic soil. Agronomy Research, vol. 14(2), 2016, pp. 495-512. 
[17] Saarsalmi A., Smolander A., Moilanen M., Kukkola M. Wood ash in boreal, low-productive pine stands on upland and peatland sites: Long-term effects on stand growth and soil properties. Forest Ecology and Management, vol. 327, 2014, pp. 86-95.

[18] Sikström U., Almqvist C., Jansson G. Growth of Pinus sylvestris after the Application of Wood Ash or P and K Fertilizer to a Peatland in Southern Sweden. Silva Fennica, vol. 44(3), 2010, pp. 411-425.

[19] Saarsalmi A., Smolander A., Kukkola M., Moilanen M., Saramäki J. 30-Year effects of wood ash and nitrogen fertilization on soil chemical properties, soil microbial processes and stand growth in a Scots pine stand. Forest Ecology and Management, vol. 278, 2012, pp. 63-70.

[20] Klavina D., Menkis A., Gaitnieks T., Velmala S., Lazdins A., Rajala T., Pennanen T. Analysis of Norway spruce dieback phenomenon in Latvia - a belowground perspective. Scandinavian Journal of Forest Research, vol. 31(2), 2016, pp. 156-165.

[21] Puhe J. Growth and development of the root system of Norway spruce (Picea abies) in forest stands - a review. Forest ecology and management, vol. 175, 2003, pp. 253-273.

[22] Ohno T. Neutralization of Soil Acidity and Release of Phosphorus and Potassium by Wood Ash. Journal of Environmental Quality, vol. 21, 1992, pp. 433-438.

[23] Indriksons A. Biogēno elementu aprite nosusinātajos mežos (Cycle of biogenous elements in drained forests). Jelgava: LLU, 2010. 155 p.

[24]Piirainen S., Domisch T., Moilanen M., Nieminen M. Long-term effects of ash fertilization on runoff water quality from drained peatland forests. Forest Ecology and Management, vol. 287, 2013, pp. 53-66. 